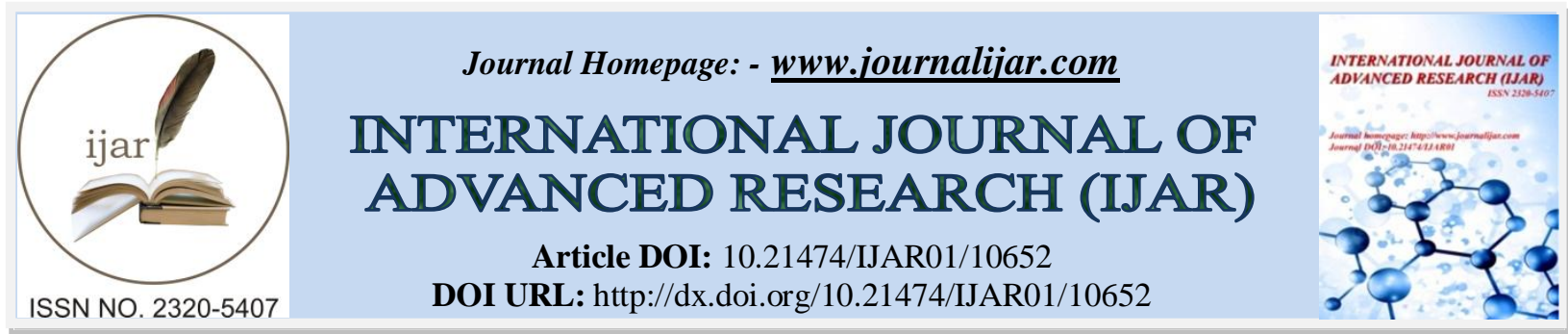

RESEARCH ARTICLE

\title{
RECONSTRUCTION OF LEGAL PROTECTION ARRANGEMENTS FOR CONSUMERS IN E- COMMERCE TRANSACTIONS BASED ON JUSTICE VALUE
}

\author{
Ukie Tukinah $^{1}$, Teguh Prasetyo ${ }^{2}$ and Anis Mashdurohatun ${ }^{3}$ \\ 1. Doctorate Student of Faculty of Law Sultan Agung Islamic University Semarang. \\ 2. Faculty of Law Pelita Harapan UniversityJakarta, Indonesia. \\ 3. Faculty of Law Sultan Agung Islamic University Semarang, Indonesia.
}

\section{Manuscript Info}

Manuscript History

Received: 10 January 2020

Final Accepted: 12 February 2020

Published: March 2020

Key words:-

Reconstruction, E-Commerce, Dignified Justice Value

\section{Abstract}

For developing countries like Indonesia, Transactions in the form of sales of goods through the internet / E-Commerce media are vulnerable to violations of consumer rights even though this type of transaction has great potential if properly developed. Based on this the authors make research with the main issue of what are the weaknesses of the legal protection arrangements for consumers in E-Commerce transactions in Indonesia today and how the reconstruction of legal protection arrangements for consumers in E-Commerce transactions based on the value of justice with dignity. The research methods used are: (1) using a constructive theory paradigm, (2) the type of qualitative research. (3) socio-legal research approach method. The results of the study showed the weakness in the protection of e-commerce transactions is UUPK no. 8 of 1999 has been unable to accommodate the rapid development of technology, especially E-Commerce related to consumer protection. This happened because the Personal Data Protection Act was not immediately enacted as a regulation. At the same time, consumer personal data is used in a number of digital applications due to the large number of complaint channels for the public, especially e-commerce consumers. For example, BPKN only acts as a recipient of complaints. For the settlement process, the authorized institution is the Consumer Dispute Settlement Agency (BPSK). This is compounded by problems in the ITE Law where information on electronic contract terms allows even leading to unbalanced standard contracts; (b) information on the terms of electronic contracts is difficult to access; and (c) information on electronic contract conditions is incomplete and unclear. In addition there is still a consumer culture that is very consumptive as well as an interaction model based solely on mercy. Therefore, it is necessary to reconstruct the formulation of Article 7 letter b of the Consumer Protection Act and Article 9 and article 13 paragraph (3) of ITE Law NO. 11 of 2008 so that the weak position of consumers in electronic commerce, can be balanced with the strong position of business actors through the terms of the contract information both in the ITE Law and the Consumer Protection Act. 
Copy Right, IJAR, 2020,. All rights reserved.

\section{Introduction:-}

Transactions in the form of selling goods through internet media are vulnerable to violations of consumer rights, for example the case of Electronic Transactions is a legal act carried out using Computers, Computer networks, and / or other electronic media.

Consumer-specific transactions on the Internet (World Wide Web) involve retail trading operators (run by individuals, families or groups, or legal entities) that accept orders from consumers and fulfill them directly from their own inventory or, if retail trading operators do not have any savings, indirectly through manufacturers or wholesalers who package and ship goods to consumers on their behalf.

Many parties agree, the biggest challenge for e-commerce in Indonesia, as with other developing countries, is getting trust from consumers. When talking about trust it is not free from risk, trust is needed because there are many violations.

In buying and selling transactions via the internet, the relevant parties in it enter into a legal relationship which is spelled out through a form of agreement or contract which is carried out electronically and in accordance with Article 1 point 17 of the Law on Information and Electronic Transactions (ITE) referred to as an electronic contract that is the agreement contained in electronic documents or other electronic media. Business actors offering goods or services electronically must provide complete and correct information regarding the terms of electronic contracts, manufacturers and products.

Electronic transactions that use standard agreements as a basis for a sale and purchase agreement potentially harm consumers' rights, because consumers cannot cancel the agreement if it turns out the producer or seller is in default or breaking a promise.

But the reality of online marketing in Indonesia, does not have a business license, because SIUP is only intended for trading businesses in a clear and real. Online marketing that shows free market practices cannot be overseen by the District / City Disperindag.

Transactions in the form of selling goods through the internet media are vulnerable to violations of consumer rights as the results of a Kaspersky Lab survey in 26 countries put Indonesia as one of the countries with the largest online fraud victims in the world with 26 percent of consumers having been victims. This condition encourages PT. Smartfren Telecom to give birth to a mobile wallet application called Uangku. This application is claimed to provide an easier and safer online transaction experience for sellers and buyers with a security guarantee.

If the order is not sent by the seller within 7 days, the payment will be returned to the buyer 100 percent, making it free of fraud. At present, Uangku has worked closely with more than 300 e-Commerce that have been strictly curated so that users can shop quietly and safely. In addition to security, Uangku also facilitates these buying and selling transactions through the automatic confirmation feature, so that buyers no longer need to send proof of transfer and sellers can manage their business administration more easily.

The reason why there are many violations according to the author is because the existence of business actors is still in doubt with the absence of a meeting between consumers and business actors at the time of the transaction. Starting from the incompatibility of goods received with ordered, fraud under the guise of electronic transactions that ask consumers to transfer funds before the goods are sent without using the services of a Joint Account (Rekber), to the difficulty of consumers filing demands for businesses that run businesses with transaction mechanisms electronic because of the lack of regulations governing e-commerce transactions related to consumer protection.

Article 1 Paragraph (3) of the Consumer Protection Act explains that the intended business actor is every individual or business entity, whether in the form of a legal entity or not a legal entity established and domiciled or carrying out activities within the legal territory of the Republic of Indonesia, both himself and together through agreements to conduct business activities in various economic fields. E-Commerce business actors are business actors who market their products through electronic transactions that can be domiciled anywhere including outside the Republic of 
Indonesia. While in the Consumer Protection Law there are restrictions that business actors are those who establish businesses and are domiciled in the jurisdiction of the Republic of Indonesia. The Electronic Information and Transaction Law (ITE) only regulates transactions, but the form of consumer protection arrangements is not touched by the law. This is evidence of the weak regulation of electronic transactions, especially E-Commerce.

The Vulnerability to violations such as the example above on online businesses to consumer rights in electronic transactions are due to the absence of information for consumers related to the background or profile of business actors and the absence of special licenses for E-Commerce businesses that sell their products via the internet such as Whats App, Facebook Messenger, Instragram, and other social networking sites. Licensing from the authorized agency to issue a business permit functions to find out the company profile including the existence / existence of the business, the address of the place of business, related to personality (the identity of the business owner), and things that can convince consumers when they will make a decision to buy or not buy.

The Department of Trade and Cooperatives gives licenses to businesses that have buildings as places of business but there are no special licenses for businesses that market their products through electronic transactions. During this time the trade service and cooperatives do not provide information facilities for consumers related to the legality of Onlineshop business actors, so consumers do not have actual information related to business actors opposed to transactions when deciding to buy or not buy. Therefore there is also a need for a preventive protection model for ECommerce consumers through information disclosure that can minimize violations of consumer rights so that consumers are comfortable in making transactions and lawsuits over cases of violations of consumer rights can be suppressed. The things above are the basis for the authors in making research that studies E-Commerce with the main issues as follows:

1. What are the weaknesses of the regulation of legal protection for consumers in E-Commerce transactions in Indonesia Currently?

2. How is the reconstruction of legal protection arrangements for consumers in E-Commerce transactions based on dignified justice?

\section{Method of Research:-}

The paradigm that is used in the research this is the paradigm of constructivism which is the antithesis of the understanding that lay observation and objectivity in finding a reality or science knowledge. Paradigm also looked at the science of social as an analysis of systematic against Socially Meaningful Action through observation directly and in detail to the problem analyzed.

The research in writing this dissertation is a qualitative research . Writing aims to provide a description of a society or a certain group of people or a description of a symptom or between two or more symptoms.

Approach ( approach ) the research is to use the approach of Socio-Legal, which is based on the norms of law and the theory of the existing legal enforceability of a sociological viewpoint as interpretation or interpretation .

As for the source of research used in this study are :

1. Primary Data, is data obtained from information and information from respondents directly obtained through interviews and literature studies.

2. Secondary Data, is an indirect source that is able to provide additional and reinforcement of research data. Sources of secondary data in the form of: Primary Legal Material and Secondary Legal Materials and Tertiary Legal Material.

In this study, researchers used data collection techniques, namely literature study, interviews and documentation. In this study, the researcher is a key instrument that is the researcher himself who plans, collects, and interprets the data. Qualitative data analysis is the process of searching for, and systematically compiling data obtained from interviews, field notes and documentation by organizing data into categories, describing it into units, synthesizing, compiling into patterns, selecting important names and what will be studied and make conclusions.

\section{Research Result and Discussion:-}

Weaknesses Of The Regulation Of Legal Protection For Consumers In E-Commerce Transactions In Indonesia Currently 
Based on the results of the study authors found a few things related to weakness in the transaction of E-Commerce where by the authors divided into three categories namely:

\section{Juridically speaking.}

Weaknesses from the Legal Protection of Consumers (PK Law)

1. Occur in the legal vacuum of consumer protection E-Commerce. At present, BPKN works to run Law No. 8 of 1999 concerning Consumer Protection. However, the Act that have been aged 20 years is rated already not able to accommodate the development of rapid trade when this, especially the development of technology, especially the development of e-commerce, related to the protection of consumer e-commerce.

2. Occurs because the Law Protection of Data Privacy did not go immediately enacted into legislation. At the moment that is the same, the data private consumer use in a number of applications digitally.

3. Occurs because of the many channels for complaints for the public, especially consumers of E- Commerce. For example, BPKN only act as agency recipient of complaints. For the settlement process, the authorized institution is the Consumer Dispute Resolution Agency (BPSK)

Weakness in the Constitution Act of Information and Technology Electronic (UU ITE ) :

1. E-commerce has the drawback that the method of transactions electronically that do not bring the perpetrators attempt to the consumer to be direct, and the non-existence of chance for consumers to view the goods directlycan potentially cause problems that harm consumers, among others are the discrepancy and quality of the goods that were promised, imprecision of the goods send time, insecurity transactions ranging from payments using other people 's credit cards ( piracy), illegal access to information systems (hacking) website damage to data theft.

2. More far longer payment through charging number card credit in within a network of public internet can also contains risks that are not small, because it opens the opportunity for fraudulence.

3. Problems transactions through e-commerce has a risk that is quite large. Special about the payment to contain the risk of losses on the part of consumers, because consumers usually are required to perform a payment up first, while he was not able to see the quality of the goods are ordered and not the guarantee of assurance that the goods are ordered will be sent according the agreement.

4. From the law of the problem among others in relation with certainty of the law. The problems are for example regarding the validity of the transaction of business of the aspects of the law of civil (as an example, if carried out by people who are not yet proficient / adult), trouble to sign digitally or electronic-hand sign and data message. In addition to the problems of others that arise for example with regard to the guarantee of the authenticity of the data, the confidentiality of documents, liability in connection with the tax laws which appointed if the case breach the agreement or contract, the issue of the jurisdiction of the law and also issues of law which should be applied when the case of disputes.

Based from the condition mentioned above it can be concluded that the weaknesess in the field of Information Transactions Electronics in Perspective ofElectronic Information and Technology law (UU ITE), includes:

1. There is a problem of jurisdiction law which has not been perfect. Where yet no arrangement in terms of which a citizen makes a software specially pornography on the outside of the country will be free from the demands of the law.

2. There is no detailed discussion about spamming.

3. Less the charge standard that is not clear, for example, standards of decency, the definition of gambling, the interpretation of an insult.

4. The emergence of moral hazard is still open using the weaknesses of supervision due to the euphoria of democracy and regional autonomy, as is sometimes the case in the implementation of $\mathrm{K} 3$ and AMDAL.

5. Preparation of the ITE Law is still made by using the procedure time, which at once do not describe their relevance to the technology that seeks arranged. In a sense, the ITE Law when it was still a bill.

6. Legislation is in the claims may restrict the right to freedom of expression, issuing opinions and could block the creativity in the internet, especially in Article 27 paragraph ( 1), Article 27 paragraph (3), Article 28 paragraph (2), and Article 31 paragraph (3).

7. UU ITE is not include and does not notice the interest element of society another, especially elements that move in the field of Information Transactions Electronic it directly .

8. Law is relatively not disseminated to the public and the preparation was entrusted in circles are very limited, and the opening is performed with no advance formerly involved in expanding the community that will be governed by the rules of the. For example, in communities Students of Computer or Engineering Informatics that will be involved in the field. 


\section{Institutionally speaking:}

1. Weakness - Weakness PP PSTE in the article mentioned above : Article 41-45 PP PSTE : Provisions provisions are written in the article that looks solely oriented on implementation of system electronics, not oriented on the relationship between the perpetrator of business with consumers ( especially consumer ECommerce)

2. Weaknesses Information Electronic Contract Terms Article 49 PP PSTE : Information on contract conditions in electronic commerce, from the consumer's perspective, should determine or influence the consumer's decision to continue until the contract closure or leave not to close the contract. Despite the limitations of the contract in B2C has been determined by the Law on the Protection of Consumers, UU ITE, and PP PSTE, but still leaves the problem in practice trade in electronics, which are not fully able to guarantee the protection of consumers.

3. Weakness Article 48 PP PSTE: Provisions are only set up in connection with the information requirements contract, namely " to provide information that is complete and correct ", while on the contract electronics regarding " provide clarity of information ". Turns on offense or do not fulfill the obligation to supply information that is complete and correct this, PP PSTE not give sanction whatsoever, including not threatened by the imposition of sanctions in administrative as stipulated by Article 84 of PP PSTE.

It are caused by logical consumers assume the risk and ease of transactions or fulfillment on goods and services that are needed are not balanced. Risk is seen more substantial than the ease of transacting or the fulfillment of the needs of consumers through the online store. More further, weaknesses BPKN: On the authority of the Agency for the Protection of Consumers National in Act No. 8 year 1999 are among others :

1. Highlighting the regulation concerning BPKN's authority which is judged half- heartedly because it only gives BPKN authority for advice and recommendations to the government.

2. BPKN conduct research only stop in the body the protection of consumers is not up to the reporting.

3. BPKN duty and authority only receives complaints from the public and agencies protection of consumer selfhelp community or actors effort, not able to resolve the case, is expected to protect the interests of consumers it should have the authority more than that.

\section{Culturally speaking:}

In a culture/cultural, there are some weaknesses that arise and need to be immediately repaired, namely :

1. First, the level of intimacy and dependency among business actors is higher than between business actors and consumers.

2. Secondly, during these actors business in Indonesia over many running activities its business based on the principle of the logic that grow and thrive in the system of economic capitalist -liberal, so it is not easy to expect the emergence of awareness of the perpetrators attempt to give attention be proportional to the interests of consumers.

3. Third, efforts to protect the consumers through the setting behavior of perpetrators of effort, shows a logic, that the circumstances of the parties are weak could be helped by a party that is economically strong. With such laws have seemed to want to build a model of interaction between actors businesses and consumers are basing on morality and ethics of "compassion pity ".

\section{Reconstruction Of Legal Protection Arrangements For Consumers In E-Commerce Transactions Based On Dignified Justice:}

Prior to reconstructing, as a comparison material, a model used by several countries regarding consumer protection was put forward, specifically relating directly or indirectly to contract terms. Consumer law is an instrumental form of law, which is organized for the achievement of efficient and honest (fair) consumer market goals. Initially evolving from the concept of bargaining power inequality, contemporary consumer law is best conceptualized as a regulation of the consumer market and includes analysis of the relative roles of public, private and self-regulatory techniques, the study of institutional policies and issues to ensure effective and accountable regulation making, regulatory and enforcement standards. This regulation crosses traditional differences between private and public law and includes soft law, moral persuasion and includes other 'non-legal' techniques. Thus the consumer protection law developed by countries explains such an idea.

Information about the contract terms is certainly very much related to the contract itself. In internet contracts (electronic contracts), the terms and conditions of a contract play a very important role, not only determining the obligations of the parties, but also establishing a mechanism that allows the parties to enter into the contract. Clear information assumes the parties when they want to enter into a contract are based on an understanding of their 
respective obligations and the mechanism for closing the contract. Therefore, terms and conditions are important because the negotiating parties must arrive at the meeting of the minds. In electronic trading the terms and conditions are certainly informed through electronic communication. To eliminate ambiguity and to prevent problems, the seller must demonstrate on his web page that every offer made by the buyer must be based on the seller's terms and conditions - as informed.

According to Alghamdi, the terms and conditions of the contract as informed are not always clear and understood, so that they can lead to error or cause confusion. In other words, there are things that cause one party to claim that they have pressed (clicked) the "I agree" button accidentally or inadvertently. Therefore, a website must be designed in such a way that the contracting parties are clearly aware that they agree to contract. Thus, the parties are prevented from claiming that they made the wrong contract. Moreover, one party can claim that he is not aware of the new terms of the contract, as they have changed when he wishes to enter into a contract. That is to say, when the terms of a proposed contract have been changed since the party wishes to contract who initially read the terms informed on the website, one party may state that he is not aware of the new terms at the time of agreement contract. In this case, a web page can play an important role in reducing the possibility of disputes. A well-made webpage can achieve an attractive and legally sufficient element. The owner of the website must be sure that the terms of the contract are easily understood and contain clear notice to guarantee that the contracting party may not claim that the terms are confusing or misleading in the future. On that basis, then as a basic rule, namely "..... for a party to be bound, the other party must have sufficient notice of the terms and that they must be brought to the first party's attention prior to the conclusion of the contract. "In the common law system, especially English law, contract terms that are informed via the web - in the case of electronic trading - are not fixed prices.

In this connection, it is known as the "battle of forms" - each party tries to win the fight with the last shot, so the contract uses the conditions it makes. In other words that:

The 'battle of forms' arises when a party (the buyer) places an order by means of a standard form that includes term and conditions that that party wants to incorporate into the contract; the other party (the seller) uses another standard form that includes the terms and conditions that he or she wants to incorporate; and the terms and conditions on the two forms are incompatible. All parties wiah to have the contract on terms of their choosing. It is important to know which form's terms will be applied.

In spite of the standard form of contract fighting, Sutatip Yuthayotin stressed that by considering the needs and interests of consumers, it is widely recognized that consumers must be given sufficient and accurate information before entering into contracts to enable them to make decisions about their transactions. Information about the identity of the seller, the goods or services offered (for example, price, quality, etc.), transaction characteristics (such as, terms and conditions regarding purchases, payment methods, etc.) and also allows consumers to assess the transaction is considered to meet the needs and affordable (the price). If consumers do not obtain enough information, then the information asymmetry that arises can reduce the efficiency of contractual exchanges and harm the functioning of the market.

The European Union has an interest in the development and regulation of "information society services". "Information Society Services" is defined as "any service, normally provided for remuneration, at a distance, by electronic means and at the request of a recipient of services". In the European Union it has been regulated in the European Community Directive (ECD), specifically regarding "distance selling directives" which are then adapted by member countries whose traditions or legal systems also vary, including by the Netherlands and the United Kingdom. Generally arranged as follows:

The Distance Selling Directive applies to any consumer distance contract made under the law of an EU-Member State as well as the European Economic Area (EEA). It provides a number of fundamental legal rights for consumers in order to ensure a high level of consumer protection throughout the EU. These include:

1. Provision of comprehensive information before the purchase;

2. Confirmation of that information in a durable medium (such as written confirmation);

3. Consumer's right to cancel the contract within a minimum of 7 working days without giving any reason and without penalty, except the cost of returning the goods (right of withdrawal);

4. Where the consumer has cancelled the contract, the right to a refund within 30 days of cancellation; 
5. Delivery of the goods or performance of the service within 30 days of the day after the consumer placed his order;

6. Protection from unsolicited selling;

7. Protection from fraudulent use of payment cards;

8. Non validity of any waiver of the rights and obligations provided for under the directive, whether instigated by the consumer or the supplier

9. Some types of contracts are excluded from all the provisions of the directive. The exemptions include contracts for financial services and contracts concluded through an auction. Contracts for financial services are covered by the Distance Marketing of Financial Services Directive 2002/65/EC.

10. Other types of contracts are excluded from the core provisions of the directive, such as the provision of comprehensible information before the purchase and the right to cancel the contract.

Then, Specifically regarding to the information for consumers are regulated in Article 4 and 5 ECD which guarantees transparency. These provisions include the issue of the identity and address of suppliers who may not be clear in the internet environment. Article 4 (1) regulates that :

1. the identity of the supplier and, in case of contracts requiring payment in advance, his address;

2. $\quad$ the main characteristics of the goods or services;

3. the price of the goods or services including all texes;

4. delivery costs, where appropriate;

5. the arrangement for payment, delivery or performance;

6. the existance of a right of withdrawal, except in the cases referred to in Article 6(3);

7. the cost of using the means of distance communication, where it is calculated other than at the basic rate;

8. the period for which the offer or the price remains valid;

Based on the explanation above, the authors argue that the Government needs to immediately issue new laws / regulations on e-commerce consumer protection specifically. However, in order for this to be done, the thing that needs to be corrected first is to make changes to the formulation of Article 7 letter b of the Consumer Protection Act and Article 9 and article 13 paragraph (3) of ITE Law NO. 11 of 2008 is based on the value of dignified justice.

With this reconstruction the author presents the Theory of Consumer Protection in Balance. The Meaning of Balanced Consumer Protection in the context of consumer protection of electronic commerce, i.e. the weak position of consumers in electronic trading, is undoubtedly balanced with the strong position of the entrepreneur through the terms of contract information both in the ITE Law and the Consumer Protection Act. The balance of the position is regulated based on a comparative approach to law mixing (mixing) between Western Law, Islamic Law and National Law. The mixing was carried out with the Concept of Harmonization of the Law. The balanced consumer protection theory contains an integrative concept. Integrative means integrating Islamic, Western and local wisdom values in constructing the law regarding contractual terms of information. However it is philosophically based also on John Rawls's justice theory that the economically weak must be given additional strength for balanced consumer protection. As for the concept of protection, in relation to information on contractual terms using models from various legal systems, both from the Netherlands, Britain and America, at least about the norm formulation.

\section{Conclusion:-}

The weakness in protecting E-Commerce Transactions is UUPK No. 8 of 1999 has been unable to accommodate the rapid development of technology, especially E-Commerce related to consumer protection. This happened because the Personal Data Protection Act was not immediately enacted as a regulation. At the same time, consumer personal data is used in a number of digital applications due to the large number of complaint channels for the public, especially e-commerce consumers. For example, BPKN only acts as a recipient of complaints. For the settlement process, the authorized institution is the Consumer Dispute Settlement Agency (BPSK). This is compounded by problems in the ITE Law where information on electronic contract terms allows even leading to unbalanced standard contracts; (b) information on the terms of electronic contracts is difficult to access; and (c) information on electronic contract conditions is incomplete and unclear. In addition there is still a consumer culture that is very consumptive as well as an interaction model based solely on mercy.

The government needs to immediately issue new laws / regulations on consumer e-commerce protection specifically. However, in order for this to be done, the thing that needs to be corrected first is to make changes to the formulation of Article 7 letter b of the Consumer Protection Act and Article 9 and article 13 paragraph (3) of ITE 
Law NO. 11 of 2008 based on the value of dignified justice. With this reconstruction presents Theory of Consumer Protection in Balance. The Meaning of Balanced Consumer Protection in the context of consumer protection of electronic commerce, i.e. the weak position of consumers in electronic trading, can be balanced with the strong position of business actors through the terms of contract information both in the ITE Law and the Consumer Protection Act. The balance of the position is regulated based on a comparative approach to law mixing (mixing) between Western Law, Islamic Law and National Law. The mixing was carried out with the Concept of Harmonization of the Law. The balanced consumer protection theory contains an integrative concept. Integrative means integrating Islamic, Western and local wisdom values in constructing the law regarding contractual terms of information. However it is philosophically based also on John Rawls's justice theory that the economically weak must be given additional strength for balanced consumer protection to at least about their norm formulation.

\section{References:-}

1. Abdulhadi m. Alghamdi,(2011), the law of e-commerce, e-contract, e-business, bloomington: author house, p. 225

2. Anjani, margaretha \& santoso, budi. (2018). Urgensi rekonstruksi hukum e-commerce di indonesia. Law reform. 14. 89. 10.14710/lr.v14i1.20239.

3. Asmara, teguh \& handayani, tri. (2019). Ketidakpastian hukum penggunaan kode unik dalam sistem pembayaran e-commerce. Jurnal penelitian hukum de jure. 19. 503. 10.30641/dejure.2019.v19.503-516.

4. Cline, h.. (2002). John rawls' law of peoples: some of the important themes and issues raised. Essays in philosophy. 3. 10.5840/eip20023s1.

5. Faisal,(2010), menerobos positivisme hukum, rangkang education, yogyakarta.

6. Hidayah, ardiana. (2019). Konsep pembangunan hukum e-commerce. Solusi. 17. 106-113. 10.36546/solusi.v17i2.168.

7. Johnny ibrahim,(2005), teori dan metodologi penelitian hukum normatif, bayumedia, surabaya.

8. L. Moleong,(2002), metode penelitian kualitatif, pt remaja rosdakarya, bandung.

9. Setyowati, dewi \& putra, candra \& saputro, ramdhan. (2019). Perlindungan hukum pada tindak pidana ecommerce. Perspektif hukum. 18. 215. 10.30649/phj.v18i2.160.

10. Sutatip yuthayotin,(2015), access to justice in transnational b2c e-commerce, a multidimentional analysis of consumer protection mechanisms, switzerland: springer, p.1. 